\title{
ANALISIS YURIDIS TERHADAP AKIBAT HUKUM PUTUSAN PERNYATAAN PAILIT BAGI DEBITOR TERHADAP KREDITOR PEMEGANG HAK TANGGUNGAN*
}

\author{
Umul Khair \\ Sekolah Tinggi Ilmu Hukum Putri Maharaja Payakumbuh \\ e-mail: umul.khair01@gmail.com
}

\begin{abstract}
The research and discussion of the problems as outlined in this scientific work is done with the aim of knowing which legal provisions apply to the creditors holding the Mortgage Rights in the case of the decree of declaration of bankruptcy, considering there are two different legal provisions, namely Bankruptcy Law Number 37 of 2004 and Insurance Rights Act No. 4 of 1996. This research is a Yuridi Normative research. Data obtained through literature research. The purpose of library research is to obtain secondary data. Primary data obtained through library research, then the data were analyzed qualitatively. From the result of the research, it is known that the Commercial Court judge in determining the decision of bankruptcy statement based its decision on the provisions of Law No. 34 of 2004, and the judges use legal principle of lex posteriori derogate legi priori to determine which legal provisions should be applied. Thus, both the bankrupt debtor and the creditor are subject to the provisions of bankruptcy, so that the holder of the mortg who has the position of the preferred creditor can only exercise his / her right of execution of the burden of the mortgage for a period of two months after a ninety-day suspension period since the bankruptcy decision was pronounced.
\end{abstract}

Keywords: Due to Law, Debtor, Creditor, Deposit Rights

\begin{abstract}
Abstrak
Penelitian dan pembahasan masalah yang dituangkan di dalam karya ilmiah ini dilakukan dengan tujuan untuk mengetahui ketentuan hukum mana yang berlaku bagi kreditor pemegang Hak Tanggungan dalam hal ditetapkan putusan pernyataan pailit, mengingat ada dua ketentuan hukum yang berbeda, yaitu Undang-Undang Nomor 37 Tahun 2004 Tentang Kepailitan dan UndangUndang Nomor 4 Tahun 1996 Tentang Hak Tanggungan. Penelitian ini merupakan penelitian Yuridi Normatif. Data diperoleh melalui penelitian kepustakaan. Maksud penelitian kepustakaan untuk memperoleh data sekunder. Data primer diperoleh melalui penelitian kepustakaan, kemudian data dianalisis secara kualitatif. Dari hasil penelitian diketahui bahwa hakim Pengadilan Niaga dalam menetapkan putusan pernyataan pailit mendasarkan putusannya pada ketentuan UndangUndang Nomor 34 Tahun 2004, dan para hakim tersebut menggunakan asas hukum lex posteriori derogate legi priori untuk menentukan ketentuan hukum mana yang harus diterapkan. Dengan demikian baik debitor pailit maupun kreditornya tunduk pada ketentuan-ketentuan kepailitan, sehingga kreditor pemegang hak tanggungan yang mempunyai kedudukan sebagai kreditor preferen hanya dapat melaksanakan hak eksekusinya atas benda yang dibebani hak tanggungan untuk selama jangka waktu dua bulan setelah menjalani masa penangguhan selama sembilan puluh hari sejak putusan pailit diucapkan.
\end{abstract}

Kata kunci : Akibat Hukum, Debtor, Kreditor, Hak Tanggungan

\footnotetext{
${ }^{*}$ Naskah diterima: 24 Februari 2018, direvisi: 11 Maret 2018, disetujui untuk terbit: 28 Maret 2018
} 
Umul Khair: Analisis Yuridis Terhadap Akibat Hukum Putusan Pernyataan Pailit Bagi...

\section{PENDAHULUAN}

Pada pertengahan tahun 1997 negaranegara Asia dilanda krisis moneter yang telah memporandakan sendi-sendi perekonomian. Dunia usaha merupakan dunia yang paling menderita dan merasakan dampak krisis yang tengah melanda. Indonesia memang tidak sendiri dalam merasakan dampak krisis tersebut, namun tidak dapat di pungkiri bahwa negara kita adalah salah satu negara yang paling menderita dan merasakan akibatnya. Selanjutnya tidak sedikit dunia usaha yang gulung tikar, sedangkan yang masih dapat bertahanpun hidupnya menderita. Untuk mengantisipasi adanya kecenderungan dunia usaha yang bangkrut yang akan berakibat pula pada tidak dapat dipenuhinya kewajiban-kewajiban yang sudah jatuh tempo, maka pemerintah melakukan perubahan-perubahan yang cukup signifikan dalam peraturan perundang-undangan, salah satunya adalah dengan melakukan revisi undang-Undang kepalitan yang ada.

Inisiatif pemerintah untuk merevisi undang-undang kepalitan, sebenarnya timbul karena adanya tekanan dari International Monetery Fund (IMF), yang mendesak supaya Indonesia menyempurnakan sarana hukum yang mengatur permasalahan pemenuhan kewajiban oleh debitor kepada kreditor. IMF merasa bahwa peraturan kepailitan yang merupakan warisan pemerintah kolonial Belanda selama ini kurang memadai dan kurang dapat memenuhi tuntutan zaman. Indonesia tidak dapat mengelak desakan IMF yang seolah-olah mendikte tersebut. Setelah negara kita hampir bangkrut karena krisis ekonomi yang berkepanjangan, IMF bagaikan dewa penolong yang memberikan setetes air dalam kehausan. Namun untuk dapat menikmati bantuan IMF tersebut mau tidak mau Indonesia harus mengikuti aturan main yang telah disusun sedemikian rupa oleh IMF agar bantuan yang berupa hutang tersebut mengucur ke Indonesia untuk dapat mempertahankan napas ditengah-tengah kesulitan ekonomi yang menghimpit Indonesia.

Dengan makin terpuruknya kehidupan perekonomian nasional, sudah dapat dipastikan akan makin banyak dunia usaha yang ambruk dan rontok sehingga tidak dapat meneruskan kegiatannya termasuk dalam memenuhi kewajiban kepada kreditor. Keambrukan itu akan menimbulkan masalah besar jika aturan main yang ada tidak lengkap dan sempurna.

Untuk itu perlu ada aturan main yang dapat digunakan secara cepat, terbuka dan efektif sehingga dapat memberikan kesempatan kepada pihak kreditor dan debitor untuk mengupayakan penyelesaian yang adil. ${ }^{1}$

Salah satu sarana hukum yang menjadi landasan bagi penyelesaian utang piutang dan relevansinya dengan kebangkrutan dunia usaha adalah peraturan kepailitan, termasuk peraturan tentang penundaan kewajiban pembayaran utang. Sebelum Undang-Undang Kepailitan Nomor 37 Tahun 2004 dikeluarkan, masalah kepailitan dan penundaan kewajiban pembayaran utang di Indonesia diatur di dalam Faillisement Verordening Peraturan Kepailitan (Staatblad 1905 Nomor 217 junto staatblad Tahun 1906 Nomor 348). Dalam masa-masa tersebut, hingga dilakukan revisi atas Undang-undang Kepailitan, urusan kepailitan merupakan suatu yang jarang muncul ke permukaan. Kekurangan populeran masalah kepailitan ini karena banyak pihak yang kurang puas terhadap pelaksanaan kepailitan.

1 Ahmad Yani, dan Gumawan Wijaya, 2002, Seri Hukum Bisnis, Kepailitan, Raja Grafindo Persada, Jakarta, Hlm. 1-2 
Banyaknya urusan kepailitan yang tidak tuntas, lamanya waktu persidangan yang diperlukan, tidak adanya kepastian hukum yang jelas, merupakan beberapa dari sekian alasan yang ada. Secara psikologis mungkin hal ini dapat diterima, karena setiap pernyataan kepailitan berarti hilangnya hakhak kreditor, atau bahkan hilangnya nilai piutang karena harta kekayaan debitor yang dinyatakan pailit itu tidak mencukupi untuk menutupi semua kewajibannya kepada kreditor.

Akibatnya dalam peristiwa kepailitan, tidak semua kreditor setuju dan bahkan akan berusaha keras untuk menentangnya. Perubahan atas Peraturan Kepailitan (Failissements Verordening-Staatsblad 1905 Nomor juncto Staatsbald Tahun 1906 Nomor 348), pertama kali ditetapkan dalam bentuk Peraturan Pemerintah Pengganti Undangundang pada tanggal 22 April 1998, Tentang perubahan atas Undang-undang tentang Kepailitan. Peraturan Pemerintah pengganti Undang-undang ini selanjutnya ditetapkan menjadi Undang-undang Nomor 4 Tahun 1998. Dalam prakteknya pelaksanaan Undang-Undang Kepalitan Nomor 4 Tahun 1998 ini mengalami berbagai masalah sehingga akhirnya dilakukan revisi yang kemudian dengan perubahan-perubahan tersebut ditetapkan menjadi Undang-Undang Kepailitan Nomor 37 Tahun 2004 yang mulai berlaku sejak 18 Oktober 2004.

Dengan adanya revisi terhadap peraturan kepailitan dan penundaan kewajiban pembayaran diharapkan dapat memecahkan sebagian persoalan penyelesaian utang piutang. Selanjutnya selain untuk memenuhi kebutuhan dalam rangka penyelesaian utang piutang tersebut diatas perlu ada mekanisme penyelesaian sengketa yang adil, cepat, terbuka dan efektif melalui suatu pengadilan khusus di lingkungan Peradilan Umum yang dibentuk secara khusus dan diberikan tugas tertentu di bidang perniagaan termasuk di bidang kepailitan dan penundaan pembayaran.

Hak eksekusi kreditor khususnya pemegang Hak Tanggungan terhadap harta kekayaan debitor yang telah dijadikan jaminan oleh debitor pailit atas kewajibankewajibannya, diatur di dalam Pasal 56 Ayat 1, Undang-undang Kepailitan Nomor 37 Tahun 2004. Di samping ketentuan tersebut, hak eksekusi kreditor pemegang Hak Tanggungan juga di dalam Undang-Undang Nomor 4 Tahun 1996, Tentang Hak Tanggungan Atas Beserta Benda-Benda Yang Berkaitan Dengan Tanah yang mulai berlaku sejak tanggal 9 April 1996. Pasal 21 UndangUndang Nomor 4 Tahun 1996 Tentang Hak Tanggungan Atas Tanah Beserta Bendabenda Yang Berkaitan Dengan Tanah menyebutkan bahwa apabila pemberi hak tanggungan dinyatakan pailit, pemegang Hak Tanggungan tetap berwenang melakukan segala hak yang diperolehnya menurut ketentuan Undang-undang tersebut.

Di dalam penjelasannya lebih lanjut ditegaskan bahwa ketentuan Pasal 21 Undang-Undang Hak Tanggungan Nomor 4 Tahun 1996 tersebut adalah untuk lebih memantapkan kedudukan diutamakan pemegang Hak Tanggungan dengan mengecualikan berlakunya akibat kepailitan pemberi Hak tanggungan terhadap objek Hak Tanggungan. Di dalam Undang-Undang Kepailitan Nomor 37 Tahun 2004, tidak ditemukan ketentuan yang mengatur mengenai bagaimana hubungan ketentuan Pasal 56 ayat 1 Undang-Undang Kepailitan Nomor 37 Tahun 2004 dengan ketentuan Pasal 21 Undang-Undang Hak Tanggungan Nomor 4 tahun 1996. 
Umul Khair: Analisis Yuridis Terhadap Akibat Hukum Putusan Pernyataan Pailit Bagi...

Akibat dari ketidakjelasan tersebut akan menimbulkan ketidakpastian hukum, terutama bagi kreditor pemegang Hak Tanggungan. Untuk mengkaji lebih lanjut, maka penulis mengangkat dalam suatu penelitian dengan judul: "Analisis Yuridis terhadap akibat Hukum Putusan Pernyataan Pailit bagi debitur terhadap Kreditor Pemegang Hak Tanggungan”.

\section{METODE PENELITIAN}

Berdasarkan perumusan masalah dan tujuan penelitian, maka metode pendekatan yang digunakan adalah metode yuridis normatif, karena mempelajari dan meneliti hubungan timbal balik antara hukum dengan lembaga-lembaga sosial yang lain.

Spesifikasi Penelitian ini adalah penelitian deskriptif analitis. Penelitian ini melakukan analisis hanya sampai pada taraf deskripsi, yaitu menganalisis dan menyajikan fakta secara sistematis sehingga dapat lebih mudah untuk dipahami dan disimpulkan. Deskriptif dalam arti bahwa dalam penelitian ini, penulis bermaksud untuk menggambarkan dan melaporkan secara rinci, sistematis dan menyeluruh, mengenai segala sesuatu yang berkaitan dengan akibat hukum putusan pernyataan pailit bagi debitor terhadap kreditor pemegang hak tanggungan.

Populasi adalah seluruh objek atau seluruh individu atau seluruh gejala atau seluruh kejadian atau seluruh unit yang akan diteliti. Populasi dalam penelitian ini adalah semua pihak yang terkait dengan putusan pernyataan pailit bagi debitor terhadap kreditor pemegang hak tanggungan, yaitu Hakim Pengadilan

Niaga, Kreditor pemegang Hak Tanggungan, Kurator dan Hakim Pengawas. Dalam penelitian ini, teknik penarikan sampel yang digunakan oleh penulis adalah teknik purposive non random sampling, ${ }^{2}$ sehingga subjeksubjek yang dituju dapat diperoleh dan berguna bagi penelitian ini.

Dalam penelitian hukum, mencakup bahan hukum primer, yaitu bahan-bahan hukum yang mengikat. Bahan hukum sekunder memberikan penjelasan mengenai bahan hukum primer dan bahan hukum tersier, yaitu bahan hukum yang memberikan petunjuk maupun penjelasan terhadap bahan hukum primer dan sekunder. Data tersebut antara lain: bahan Hukum Primer, yaitu bahan hukum yang mengikat yang meliputi: Kitab UndangUndang Hukum Perdata (KUHPerdata), Kitab Undang-Undang Hukum Dagang (KUHD), Undang-Undang Nomor 37 Tahun 2004 Tentang Kepailitan, UndangUndang Nomor 4 Tahun 1998 Tentang Penetapan Peraturan Pemerintah Pengganti Undang-Undang Nomor 1 Tahun 1998 Tentang Perubahan atas undang-Undang Tentang Kepailitan, Undang-Undang Nomor 4 Tahun 1996 Tentang Hak Tanggungan atas Tanah Beserta Benda-Benda Yang Berkaitan dengan Tanah, sedangkan bahan Hukum Sekunder, Yaitu bahan hukum yang memberikan penjelasan mengenai bahan hukum terdiri dari: berbagai bahan perpustakaan yang membahas mengenai

Ronny Hanitijo Soemitro, 1988, Metodologi Penelitian Hukum Dan Jurimetri, Ghalia Indonesia, Hlm. 44 
kepailitan, berbagai bahan perpustakaan yang membahas mengenai hak tanggungan dan berbagai hasil penelitian mengenai kepailitan dan hak tanggungan, hasil seminar, lokakarya dan simposium mengenai kepailitan dan hak tanggungan, bahan Hukum Tertier yaitu bahan hukum yang memberikan petunjuk maupun penjelasan terhadap bahan hukum primer dan bahan hukum sekunder meliputi: Kamus Hukum dan Kamus Umum bahasa Indonesia.

Dari data-data telah diperoleh baik dari penelitian kepustakaan maupun penelitian lapangan kemudian dikumpulkan, diseleksi dan diklasifikasikan untuk mempermudah melakukan analisisnya, yang dilakukan secara kualitatif dengan metode deskriptif. Analisis yang dilakukan secara kualitatif adalah analisis data yang mengelompokkan dan menyeleksi data yang diperoleh dari penelitian lapangan menurut kualitas dan kebenarannya, kemudian dihubungkan dengan teoriteori yang diperoleh dari studi kepustakaan sehingga diperoleh jawaban atas permasalahan yang diajukan. Dalam analisis menggunakan cara berpikir induktif, yaitu menyimpulkan hasil penelitian dari hal yang sifatnya khusus ke hal yang sifatnya umum. ${ }^{3}$

3 Fuady, Munir, 2002, Hukum Pailit 1998 Dalam Teori dan Praktek, Citra Aditya Bakti, Bandung, Hlm. 23

\section{HASIL DAN PEMBAHASAN}

Analisis Yuridis terhadap Akibat Hukum Yang Timbul Terhadap Putusan Pernyataan Pailit Bagi Debitor Terhadap Kreditor

Putusan pernyataan pailit membawa akibat hukum yang baik bagi debitor pemberi Hak Tanggungan maupun kreditor pemegang Hak Tanggungan. Dengan adanya putusan pernyataan pailit mengakibatkan harta kekayaan debitor sejak putusan tersebut dikeluarkan, masuk menjadi harta pailit (faillieten boedel), debitor pailit demi hukum kehilangan hak penguasaan dan hak Tanggungan (kreditor preferen) yang mempunyai hak separatis, ditangguhkan untuk jangka waktu 90 hari.

Jika melihat ketentuan tentang hak eksekusi kreditor pemegang Hak Tanggungan, ada dua ketentuan hukum yang mengatur mengenai pelaksanaan hak dari para kreditor pereferen setelah adanya putusan pernyataan pailit untuk dapat mengambil pelunasan atas piutangpiutangnya yaitu, Undang-Undang Kepailitan Nomor 37 Tahun 2004 dan Undang-Undang Hak Tanggungan Nomor 4 Tahun 1996. Di dalam Undang-Undang Kepailitan pengakuan hak separatis dari kreditor preferen diwujudkan di dalam Pasal 55 ayat 1 Undang-Undang Kepailitan Nomor 37 Tahun 2004, yang menyebutkan bahwa setiap kreditor yang memegang Hak Tanggungan, Gadai, Jaminan Fidusia, Hipotek, atau Hak Agunan atas kebendaan lainnya, dapat mengeksekusi haknya seolah-olah tidak terjadi kepailitan dengan tetap 
Umul Khair: Analisis Yuridis Terhadap Akibat Hukum Putusan Pernyataan Pailit Bagi...

memperhatikan ketentuan-ketentuan Pasal 56, Pasal 57 dan Pasal 58 Undang-undang Kepailitan.

Akan tetapi pengaturan yang kontradiksi dengan Pasal 56 ayat 1 Undang-Undang Kepailitan Nomor 37 Tahun 2004, hak preferen dari kreditor pemegang Hak Tanggungan untuk mengeksekusi hak atas tanah yang dibebani Hak Tanggungan ditangguhkan pelaksanaannya (stay) untuk jangka waktu paling lama 90 hari terhitung sejak putusan pernyataan pailit diucapkan. ${ }^{4}$

Dalam penjelasan Pasal 56 ayat 1 Undang-Undang Kepailitan Nomor 37 Tahun 2004 tersebut dinyatakan bahwa maksud penangguhan ini bertujuan antara lain untuk memperbesar kemungkinan tercapainya perdamaian atau untuk memperbesar kemungkinan mengoptimalkan harta pailit atau untuk memungkinkan kurator melaksanakan tugasnya secara optimal. Selama berlangsungnya jangka waktu penangguhan segala tuntutan hukum untuk memperoleh pelunasan atas suatu piutang tidak dapat diajukan dalam sidang badan peradilan, dan bagi kreditor pihak ketiga dimaksud dilarang mengeksekusi atau memohonkan sita atas benda yang menjadi agunan.

Ketentuan Pasal 56 ayat 1 UndangUndang Kepailitan justru mengingkari hak separatis kreditor pemegang Hak Tanggungan yang diakui oleh Pasal 55 ayat 1 Undang-Undang Kepailitan, karena

\footnotetext{
Kartono, 1985, Kepailitan dan Pengundurna Pembayarann, Pradnya Paramita, Jakarta, Hlm. 30
}

menentukan bahwa yang dibebani dengan Hak Tanggungan merupakan harta pailit. Ketentuan hukum yang menentukan terjadinya keadaan yang disebut standstill atau automatic stay, yaitu keadaan status quo bagi debitor dan para kreditor, biasanya diberikan oleh undang- undang bukan setelah debitor dinyatakan pailit oleh pengadilan, tetapi justru selama berlangsungnya pemeriksaan pailit yaitu sejak permohonan pernyataan pailit didaftarkan oleh pengadilan, atau diberikan selama dilakukan negosiasi antara debitor dan para kreditor dalam rangka rektruksisasi utang.

Setelah debitor dinyatakan pailit yang terjadi hanyalah likuidasi terhadap harta pailit. Selama masa penundaan (stay) kurator dapat menggunakan harta pailit berupa benda bergerak atau tidak bergerak atau menjual harta pailit yang berupa benda bergerak yang berada dalam pengawasan curator dalam rangka kelangsungan usaha debitor, sepanjang untuk itu telah diberikan perlindungan yang wajar bagi kepentingan kreditor atau pihak ketiga (Pasal 56 ayat 3 UndangUndang Kepailitan).

Di sini terlihat bahwa UndangUndang Kepailitan tidak memisahkan benda-benda yang dibebani Hak Tanggungan sebagai benda yang bukan merupakan harta pailit. Sehingga membuat lembaga Hak tanggungan menjadi tidak ada artinya, filosofi dan tujuan dari adanya Hak Tanggungan menjadi kabur.

Pasal 59 ayat 1 Undang-Undang Kepailitan Nomor 37 Tahun 2004, 
menentukan bahwa kreditor pemegang saham Hak Tanggungan baru dapat melaksanakan hak eksekusinya dalam jangka waktu paling lambat 2 bulan terhitung sejak dimulainya keadaan insolvensi sebagaimana dimaksud dalam Pasal 178 ayat 1 Undang-Undang Kepailitan Nomor 37 Tahun 2004. Apabila dalam jangka waktu tersebut pemegang Hak Tanggungan belum melaksanakan hak eksekusinya terhadap benda yang menjadi agunan, maka kurator harus menuntut kepada kreditor pemegang Hak Tanggungan untuk menyerahkan benda yang menjadi agunan tersebut untuk selanjutnya dijual sesuai dengan cara-cara yang diatur oleh Pasal 185 Undang-Undang Kepailitan No.37 tahun 2004, tanpa mengurangi hak kreditor pemegang Hak Tanggungan untuk menerima pelunasan dari hasil penjualan tersebut (Pasal 59 ayat 2 Undang-Undang Kepailitan Nomor 37 Tahun 2004).

Pasal 21 Undang-Undang hak Tanggungan menyebutkan bahwa apabila pemberi Hak Tanggungan dinyatakan pailit, maka pemegang Hak Tanggungan tetap berwenang melakukan segala hak yang diperolehnya menurut ketentuan Undang-undang Hak Tanggungan. Hal ini berarti bahwa hak dari pemegang Hak Tanggungan tetap dijamin walaupun pemberi Hak Tanggungan dinyatakan pailit, jaminan tersebut lebih diperjelas lagi dalam Penjelasan Pasal 21 UndangUndang Hak Tanggungan yang menyebutkan bahwa ketentuan Pasal 21 Undang-Undang Hak Tanggungan tersebut lebih memantapkan kedudukan diutamakannya pemegang Hak Tanggungan dengan mengecualikan berlakunya akibat kepailitan terhadap objek Hak Tanggungan. ${ }^{5}$

Ketentuan Pasal 21 Undang-Undang Hak Tanggungan memberikan penegasan mengenai kedudukan yang preferen dari pemegang Hak Tanggungan terhadap objek Hak Tanggungan kreditor-kreditor lain. Dengan demikian objek Hak Tanggungan tidak akan disatukan dengan harta kepailitan untuk dibagikan kepada kreditor-kreditor lain dari Hak Tanggungan. Dengan ketentuan ini berarti hak separatis dari kreditor preferen pemegang Hak Tanggungan tidak terpengaruh oleh putusan pernyataan pailit. Ketentuan Pasal 55 ayat 1 UndangUndang Kepailitan adalah sejalan dengan Ketentuan Pasal 21 Undang-Undang Hak Tanggungan dan hak separatis dari pemegang hak Tanggungan sebagaimana ditentukan di dalam Kitab UndangUndang Hukum Perdata.

Sebagaimana telah disebutkan diatas bahwa salah satu alas an dilakukannya penangguhan hak pemegang Hak Tanggungan untuk mengeksekusi objek Hak Tanggungan adalah untuk memperbesar kemungkinan mengoptimalkan harta pailit, artinya bahwa debitor yang sebelum kepailitan telah dibebani dengan Hak Tanggungan merupakan harta pailit ketika debitor dinyatakan pailit.

ST. Remy Sjahdeini, 1999, Hak Tanggungan: Asas-asas, Ketentuan-ketentuan Pokok Dan Masalah Yang Dihadapi Oleh Perbankan, Alumni, Bandung, Hlm. 7 
Umul Khair: Analisis Yuridis Terhadap Akibat Hukum Putusan Pernyataan Pailit Bagi...

Dari ketentuan Pasal 56 ayat 1 dan Pasal 59 ayat 1 Undang-Undang Kepailitan Nomor 37 Tahun 2004 serta penjelasannya jelas terlihat bahwa ketentuan Pasal 56 ayat 1 dan Pasal 59 ayat 1 tersebut bertentangan dengan ketentuan Pasal 21 Undang-Undang Hak Tanggungan. Kedua Pasal 56 ayat 1 dan 59 ayat 1 tersebut menghapus kewenangan atau hak dari kreditor pemegang Hak Tanggungan yang dijamin oleh Undang-Undang Hak Tanggungan.

Sehubungan dengan adanya pertentangan antara Undang-Undang Kepailitan khususnya Pasal 56 ayat 1 dan Pasal 21 Undang-Undang Hak Tanggungan, maka timbul masalah hukum mengenai undang-undang mana yang harus diberlakukan. Membaca suatu undang-undang tidaklah mudah karena tidak sekedar membaca bunyi katakatanya saja (naar de letter van de wet), tetapi harus pula mencari arti, makna atau tujuannya. Jadi membaca suatu Undangundang tidaklah cukup dengan membaca Pasal-Pasalnya saja, tetapi harus pula dibaca penjelasan-penjelasannya dan juga konsiderennya. Bahkan mengingat bahwa hukum itu adalah suatu sistem, maka untuk memahami suatu Pasal dalam undang-undang atau untuk memahami suatu undang-undang sering harus dibaca juga Pasal-pasal lain dalam satu undangundang itu atau peraturan perundangundangan yang lain.

Membaca Undang-Undang Kepailitan secara keseluruhan mulai dari konsiderens sampai dengan penjelasannya, penulis menemukan tidak ada satupun ketentuan yang menyinggung mengenai hubungan ketentuan-ketentuan kepailitan dengan peraturan yang tercantum di dalam Undang-Undang Hak Tanggungan khususnya Pasal 21. Sehingga terkesan bahwa ketika merancang undang-undang tersebut pembuat Undang-Undang Kepailitan melupakan atau tidak memperhatikan perundang-undangan yang terkait lainnya yang seharusnya dilakukan secara komprehensif.

Dari hasil penelitian yang dilakukan terhadap beberapa putusan hakim Pengadilan Niaga, semua perkara kepailitan diperiksa dan diputus berdasarkan Undang-undang kepailitan dan sama sekali tidak menyinggung ketentuan Pasal 21 Undang-Undang Hak Tanggungan. Segala akibat hukum atas pernyataan pailit baik bagi debitor pailit maupun kreditornya adalah tunduk pada ketentuan-ketentuan kepailitan.

Dari uraian tersebut diatas dapat diketahui bahwa ketentuan Pasal 56 ayat 1 dan Pasal 59 ayat 2 Undang-Undang Kepailitan telah mengabaikan berlakunya hak separatis dari kreditor pemegang hak Tanggungan, serta kreditor sebagai pemegang hak Tanggungan telah kehilangan kedudukan sebagai kreditor preferen, di samping itu juga ketentuan Pasal 59 ayat 1 dan ayat 2 adalah tidak realistis. Di dalam praktik sangat sulit dan bahkan hampir tidak mungkin bisa dilakukan penjualan benda yang menjadi agunan dalam jangka waktu 2 bulan. Misalnya sebuah bank yang menerima sebuah pabrik tekstil atau sebuah hotel 
berbintang sebagai agunan berdasarkan pembinaan Hak Tanggungan, amat sulit untuk melakukan penjualan benda agunan tersebut dalam jangka waktu 2 bulan. Proses penjualan mulai dari persiapan transaksi kemudian pelaksanaan jual beli sampai kepada penyelesaian pembayaran pabrik tekstil atau hotel berbintang tersebut dapat memakan waktu lebih dari dua bulan, bahkan bisa sampai 1 tahun atau 2 tahun.

Penetapan ketentuan bahwa hak eksekusi kreditor pemegang Hak Tanggungan harus ditangguhkan untuk jangka waktu selama 90 hari sebagaimana ditetapkan oleh ketentuan Pasal 56 ayat 1 Undang-undang Kepailitan merupakan ketentuan yang dapat merugikan kreditor pemegang Hak Tanggungan yang mempunyai kedudukan sebagai kreditor preferen atau yang diutamakan (asas droit de preference). Peluang kerugian yang mungkin terjadi adalah kreditor pemegang Hak Tanggungan akan kerugian yang mungkin terjadi adalah kreditor pemegang Hak Tanggungan mendapatkan calon pembeli yang bersedia membeli benda yang menjadi jaminan tersebut dengan harga mahal, akan tetapi kreditor pemegang Hak Tanggungan tidak dapat melaksanakan hak eksekusinya karena adanya masa penangguhan tersebut dan kesempatan tersebut belum tentu bisa diperolehnya pada saat masa penangguhan berakhir. ${ }^{6}$

6 J Satrio, 2000, Hukum Jaminan Hak Jaminan Kebendaan, Citra Aditya Bakti, Bandung, Hlm. 38
Jika benda yang dijadikan jaminan berupa rumah atau gedung yang tidak ditempati, maka masa penangguhan tersebut dapat menurunkan nilai atau harga jualnya karena ada kemungkinan rumah atau gedung yang tidak ditempati tersebut selama masa penangguhan mengalami kerusakan yang mengakibatkan menurunnya nilai atau harga jualnya. Lebih jauh lagi karena adanya masa penanggungan, parate eksekusi yang diberikan oleh UndangUndang Hak Tanggungan sebagaimana ditentukan di dalam pasal 6 menjadi tidak berguna lagi. Karena tujuan untuk memberikan kemudahan dan kepastian bagi kreditor pemegang Hak Tanggungan untuk melakukan hak eksekusi atas Hak Tanggungan menjadi tidak terwujud.

\section{Penyelesaian Hukum Dan Kriteria Yang Digunakan Dalam Menentukan Hukum Yang Berlaku}

Dari uraian tersebut diatas dapat diketahui bahwa semua perkara kepailitan diperiksa dan diputus oleh Hakim Pengadilan Niaga sesuai dengan ketentuan yang tercantum di dalam Undang-Undang Kepailitan, sehingga timbul permasalahan kedua dari tesis ini yaitu kriteria atau tolok ukur apa yang digunakan oleh Hakim sehingga 90 mereka memeriksa dan memutus perkara kepailitan semata-mata hanya berdasarkan Undang-Undang Kepailitan, tanpa memperhatikan ketentuan-ketentuan terkait lainnya yang ada di dalam Undang -Undang Hak Tanggungan.

Pada hakekatnya yang dilakukan oleh hakim di dalam menghadapi suatu kasus 
Umul Khair: Analisis Yuridis Terhadap Akibat Hukum Putusan Pernyataan Pailit Bagi...

adalah hakim harus menyelesaikannya dan untuk itu hakim harus tahu, mencari dan menemukan hukumnya untuk diterapkan pada kasus tersebut. Menurut pandangan klasik semua hukum terdapat secara lengkap dan sistematis dalam undang-undang dan tugas hakim adalah mengadili sesuai atau menurut bunyi undang-undang. ${ }^{7}$

Tugas hakim untuk memeriksa dan memutus suatu perkara diajukan kepadanya dan hakim tidak boleh menolak dengan alas an bahwa hukumnya tidak jelas atau tidak ada, hal ini selaras dengan fungsi hakim sebagai corong Undang-undang. Dalam menentukan ketentuan hukum yang berlaku untuk menyelesaikan kasus-kasus kepailitan, hakim Pengadilan Niaga berpedoman pada asas hukum yang dapat digunakan oleh hakim untuk dapat menentukan hukum yang harus diterapkan, yaitu asas hukum yang dikenal dengan asas Lex Posteriori derogat legi priori yaitu jika terjadi konflik antara Undang-undang yang lama dengan yang baru, dan Undang-undang yang baru tidak mencabut Undang-undang yang lama yang berlaku ialah Undang-undang yang baru. Oleh karena Undang-Undang Kepailitan Nomor 37 Tahun 2004 lebih baru daripada Undang-Undang Hak Tanggungan Nomor 4 Tahun 1996 dan dalam Undang-Undang Kepailitan tidak ada ketentuan yang menyebutkan bahwa Undang-Undang Hak Tanggungan tidak berlaku, maka yang harus dipilih adalah

\footnotetext{
7 Aria Suyudi, Eryanto Nugroho, dan Herni Sri Nurbayanti, 2004, Kepailitan Di Negeri Pailit, Dimensi, Jakarta, Hlm. 44
}

Undang-Undang Kepailitan Nomor 37 tahun 2004.

Apabila dalam melaksanakan pilihan hukum itu diberlakukan asas lex specialis derogate lex generalis, maka timbul masalah untuk menentukan mana yang lex specialis, Undang-Undang Hak Tanggungan atau Undang-undang Kepailitan, karena undang-undang tersebut sama-sama mengatur hal yang spesialis yaitu masalah kepailitan dan Hak Tanggungan. $^{8}$

Setiap putusan hakim harus memperhatikan tiga faktor yang seyogyanya diterapkan secara proposional, yaitu keadilan, kepastian hukum, dan kemanfaatan. Dalam kenyataannya mungkin sulit sekali untuk menerapkan secara proporsional ketiga faktor tersebut di dalam suatu putusan, tetapi paling tidak dalam setiap putusan ada ketiga factor tersebut.

Dalam melakukan pilihan-pilihan hukum tersebut diatas sudah seharusnya hakim memikirkan secara cermat dan hati-hati apakah pilihan hukum yang dilakukan berdasarkan pada asas lex posteriori derogate legi priori akan menghasilkan suatu putusan yang mencerminkan atau mengandung ketiga faktor tersebut diatas.

Putusan hakim harus mengandung keadilan baik bagi debitor pailit maupun bagi kreditor pemegang hak tanggungan. Putusan hakim Pengadilan Niaga yang dalam menentukan ketentuan mana yang

\footnotetext{
${ }^{8}$ Rachmadi Usman, 2004, Dimensi Hukum Kepailitan Di Indonesia, Gramedia Pustaka Utama, Jakarta, Hlm. 11
} 
berlaku bersandar pada asas lex posteriori derogate legi priori hanya adil buat debitor pailit saja, hal ini terkait dengan dasar pemikiran yang menjadi latar belakang dikeluarkannya Undang-Undang Kepailitan sebagaimana tertulis di dalam penjelasan umum atas Undang-Undang Kepailitan yang menyebutkan bahwa ada beberapa faktor perlunya pengaturan mengenai kepailitan dan penundaan kewajiban membayar utang, yaitu:

Pertama, untuk menghindari perebutan harta debitor apabila dalam waktu yang sama ada beberapa kreditor yang menagih piutangnya dari debitor.

Kedua, untuk menghindari adanya kreditor pemegang hak tanggungan yang menuntut haknya dengan cara menjual barang milik debitor tanpa memperhatikan kepentingan debitor atau para kreditor lainnya.

Ketiga, untuk menghindari adanya kecurangan-kecurangan yang dilakukan oleh salah seorang kreditor atau debitor sendiri.

Dari ketiga dasar pemikiran tersebut jelas terlihat bahwa tujuan dari Undangundang Kepailitan lebih banyak untuk melindungi kepentingan debitor, sedangkan kepentingan kreditor pemegang Hak Tanggungan sebagai kreditor preferen dan mempunyai hak parate eksekusi dimana hak tersebut telah dijamin oleh Undang-Undang Hak Tanggungan menjadi terabaikan. Jadi jelas bahwa putusan hakim dalam perkara kepailitan tersebut tidak memberi rasa keadilan yang seimbang antara debitor pailit dan kreditor pemegang hak tanggungan.

Di samping itu penetapan mengenai ketentuan mana yang berlaku yang didasarkan pada kriteria asas lex posteriori derogate legi priori tersebut tidak menghasilkan suatu putusan yang dapat memberikan kepastian hukum bagi kreditor pemegang hak tanggungan. Pada saat kreditor menerima benda agunan dari debitor sebagai pemberi hak tanggungan dimana benda agunan tersebut telah dibebani dengan hak tanggungan, maka seluruh hak dan kewajiban dari debitor dan kreditor tunduk pada ketentuanketentuan yang diatur di dalam Undangundang Hak Tanggungan yang memuat asas-asas Hak Tanggungan sebagaimana ditentukan dalam Kitab Undang-Undang Hukum Perdata, antara lain asas droit de preference serta parate eksekusi.

Hak Tanggungan merupakan hak jaminan yang dimaksudkan untuk menjamin pelunasan utang debitor yang memberikan hak utama kepada kreditor sebagai pemegang hak jaminan untuk didahulukan dalam pelunasan piutangnya terhadap kreditor-kreditor lain apabila debitor cidera janji. Akan tetapi begitu debitor dinyatakan pailit oleh suatu putusan hakim, maka akibat hukum dari putusan pailit tunduk pada ketentuanketentuan Undang-Undang Kepailitan, dimana hak kreditor untuk mengeksekusi benda jaminan hanya diberikan untuk jangka waktu selama dua bulan sejak dimulainya keadaan insolvensi setelah menjalani masa penundaan selama 90 (sembilan puluh) hari sejak adanya 
Umul Khair: Analisis Yuridis Terhadap Akibat Hukum Putusan Pernyataan Pailit Bagi...

putusan pernyataan pailit. Keadaan demikian jelas menimbulkan ketidakpastian hukum bagi kreditor, kedudukan yang diutamakan sebagai kreditor menjadi tidak ada artinya lagi karena kewenangan untuk mengambil pelunasan piutangnya yang dijamin oleh benda agunan tersebut dibatasi oleh waktu yaitu hanya selama 2 bulan.

Lebih lanjut penggunaan asas hukum lex posteriori derogate legi priori sebagai criteria atau pedoman hakim dalam menerapkan hukum yang berlaku terhadap perkara kepailitan telah menghasilkan suatu putusan pernyataan pailit yang tidak memberi manfaat bagi kreditor. Jangka waktu dua bulan yang diberikan kepada kreditor untuk mengeksekusi benda agunan sangat tidak realistis, sangat sulit sekali dalam waktu yang sedemikian singkat kreditor dapat mendapatkan pembeli. Apabila dalam jangka waktu dua bulan kreditor tidak dapat menjual benda agunan tersebut maka benda yang menjadi agunan harus diserahkan kepada kurator untuk dijual. ${ }^{9}$

Hal ini berarti status kreditor sebagai kreditor preferen berubah menjadi kreditor konkuren yang tidak lagi memiliki hak separatis, yang merupakan hak yang diberikan oleh hukum kepada kreditor bahwa agunan yang dibebani dengan hak jaminan tidak termasuk harta pailit, dan kreditor berhak untuk melakukan eksekusi berdasarkan kekuasaanya sendiri yang diberikan oleh undang-undang sebagai perwujudan dari

\footnotetext{
9 J Satrio, Op.Cit, Hlm. 17
}

hak kreditor untuk didahulukan dari pra kreditor lainnya. Sehubungan dengan berlakunya hak separatis tersebut, maka pemegang hak tanggungan tidak boleh dihalangi haknya untuk melakukan eksekusi atas hak tanggungan atas harta kekayaan debitor yang dibebani dengan hak tanggungan itu.

Undang-undang Kepailitan ternyata tidak menjunjung tinggi hak separatis dari para kreditor pemegang hak tanggungan.

\section{SIMPULAN}

Berdasarkan pembahasan terhadap permasalahan yang diteliti, dapat ditarik simpulan sebagai berikut:

1. Hakim dalam memeriksa dan memutus perkara kepailitan sematamata hanya berdasarkan pada ketentuan-ketentuan yang tertuang dalam Undang-undang Kepailitan tanpa memperhatikan ketentuan lain seperti Undang-undang Hak Tanggungan. Pemegang Hak Tanggungan yang mempunyai kedudukan sebagai kreditor yang diutamakan hanya dapat melaksanakan hak eksekusinya atas benda yang dibebani hak tanggungan untuk dua bulan setelah menjalani masa penangguhan selama 90 (sembilan puluh) hari sejak putusan pailit diucapkan.

2. Dengan berlandaskan pada asas hukum lex posteriori derogate legi priori, sebagai criteria dalam melakukan pilihan hukum, hakim telah mengeluarkan suatu putusan yang tidak memberikan rasa keadilan, 
serta kepastian hukum bagi kreditor.

Bahkan lebih jauh lagi putusan tersebut tidak memberi manfaat bagi kreditor, karena putusan hakim tersebut telah mengabaikan asas serta mengaburkan filosofi yang terkandung di dalam hak tanggungan.

\section{SARAN}

1. Dalam memeriksa dan memutus suatu perkara kepailitan hendaklah hakim tidak hanya berdasarkan pada Undang-undang Kepailitan saja, tetapi juga memperhatikan ketentuanketentuan yang tertuang dalam Undang-undang Hak Tanggungan, dengan mengecualikan berlakunya ketentuan Pasal 56 ayat 1 dan Pasal 59 ayat 1 dan 2 Undang-undang Kepailitan, sehingga ketentuan Pasal 21 Undang-undang Hak Tanggungan tetap berlaku.

2. Agar pengecualian tersebut diatas dapat diterapkan hendaklah hakim tidak mendasarkan kriteria pilihan hukum pada asas lex posteriori derogate legi priori, sehingga putusan pernyataan pailit yang dikeluarkanya dapat memberikan rasa keadilan dan kepastian hukum serta manfaat bagi kreditor.

\section{UCAPAN TERIMA KASIH}

Puji dan Syukur penulis ucapkan ke hadirat Allah SWT yang telah memberikan Rahmat dan Karunia-Nya, sehingga akhirnya penulis dapat menyelesaikan penulisan karya ilmiah ini yang berjudul: "Akibat Hukum Putusan Pernyataan Pailit Bagi Debitor Terhadap
Kreditor Pemegang Hak Tanggungan”. Sebagai salah satu dari realisasi Tridarma Perguruan Tinggi yaitu dibidang penelitian pada Sekolah Tinggi Ilmu Hukum Putri Maharaja Payakumbuh.

Sebagai manusia biasa penulis menyadari bahwa dalam penulisan dan penyajian karya ilmiah ini masih banyak kekurangan dan jauh dari kesempurnaan bila ditinjau dari segi ilmiah maupun tata bahasa, yang disebabkan karena keterbatasan kemampuan yang penulis miliki. Penulis menyadari bahwa tanpa bantuan dan dorongan dari berbagai pihak tidak mungkin karya ilmiah ini dapat diselesaikan. Oleh karena itu pada kesempatan ini dengan segala kerendahan hati, penulis ingin mengucapkan terima kasih dan penghargaan yang sebesarbesarnya kepada:

1. Bapak Dr. Eviandi Ibrahim S.H., M.Hum selaku Ketua Sekolah Tinggi Ilmu Hukum Putri Maharaja Payakumbuh.

2. Kedua orang penulis yaitu ayahanda Dasri D dan Ibunda Misda R

3. Suamiku tercinta (Mahyudin) yang memotivasi penulis dan membantu secara moril dan materil penulis dalam penyelesaian karya ilmiah ini

4. Anak-anakku tersayang penerus hidup bunda Hasrat Al-ghaffari, Aqis Al-muzaki dan Habib Al-ghazali.

5. Seluruh rekan-rekan dosen dan karyawan Sekolah Tinggi Ilmu Hukum Putri Maharaja (STIH-PM) yang tidak dapat penulis sebutkan satu-persatu. 
Umul Khair: Analisis Yuridis Terhadap Akibat Hukum Putusan Pernyataan Pailit Bagi...

Penulis menyadari bahwa karya ilmiah ini tidak luput dari kekurangan, untuk itu penulis mengharapkan kritik dan saran yang membangun guna perbaikan karya ilmiah ini. Akhirnya kepada Allah SWT penulis berserah diri dan semoga karya ilmiah ini dapat bermanfaat, Amin.

\section{DAFTAR PUSTAKA}

\section{Buku}

Fuady, Munir, 2002, Hukum Pailit 1998 Dalam Teori dan Praktek, Citra Aditya Bakti, Bandung.

Kartono, 1985, Kepailitan dan Pengundurna Pembayarann, Pradnya Paramita, Jakarta.

Mertokusumo, Sudikno, 2002, Hukum Acara Perdata Indonesia, Liberty, Yogyakarta.

Mertokusumo, Sudikno, 2001, Penemuan Hukum Sebuah Pengantar,Liberty, Yogyakarta.

Satrio, J, 2000, Hukum Jaminan Hak Jaminan Kebendaan, Citra Aditya Bakti, Bandung.

Situmorang, Victor M., Hendri Soekarso, 1994, Pengantar Hukum Kepailitan Di Indonesia, Rineka Cipta: Jakarta.

Sjahdeini, ST. Remy, 2004, Hukum Kepailitan, Memahami Failissementsverordening Juncto Undang-Undang Nomor 4 Tahun 1998, Pustaka Utama Grafiti, Jakarta.

Sjahdeini, ST. Remy, 1999, Hak Tanggungan: Asas-asas, Ketentuanketentuan Pokok Dan Masalah
Yang Dihadapi Oleh Perbankan, Alumni, Bandung.

Soekardono, R, 1982, Hukum Dagang Indonesia Kapita Selekta, Rajawali, Jakarta.

Soemitro, Ronny Hanitijo, 1988, Metodologi Penelitian Hukum Dan Jurimetri, Ghalia Indonesia, Jakarta.

Subekti, 1980, Poko-pokok Humum Perdata, Intermassa, Jakarta.

Suyudi, Aria dan Eryanto Nugroho, dan Herni Sri Nurbayanti, 2004, Kepailitan Di Negeri Pailit, Dimensi, Jakarta.

Usman, Rachmadi, 2004, Dimensi Hukum Kepailitan Di Indonesia, Gramedia Pustaka Utama, Jakarta.

Yani, Ahmad dan Gumawan Wijaya, 2002, Seri Hukum Bisnis, Kepailitan, Raja Grafindo Persada, Jakarta.

\section{Peraturan Perundang-Undangan}

Undang-Undang Republik Indonesia Nomor 4 Tahun 1996 Tentang Hak Tanggungan Atas Tanah Beserta Banda-Benda Yang Berkaitan Dengan Tanah.

Undang-undang Republik Indonesia Nomor 37 Tahun 2004 Tentang Kepailitan Dan Penundaan Kewajiban Pembayaran Utang. 